\title{
B cells from rheumatoid arthritis patients show important alterations in the expression of CD86 and FcyRllb, which are modulated by anti-tumor necrosis factor therapy
}

Diego Catalán ${ }^{1}$, Octavio Aravena ${ }^{1}$, Francisca Sabugo ${ }^{2}$, Pamela Wurmann $^{2}$, Lilian Soto², Alexis M Kalergis ${ }^{3}$, Miguel Cuchacovich², Juan C Aguillón ${ }^{1 *}$, Millenium Nucleus on Immunology and Immunotherapy P-07-088-F

\begin{abstract}
Introduction: Several molecules help preserve peripheral B cell tolerance, but when altered, they may predispose to autoimmunity. This work studied the expression of the costimulatory molecule CD86 and the inhibitory receptor for lgG immune complexes FcyRllb (CD32b), on B cells from rheumatoid arthritis (RA) patients, and the influence of anti-tumor necrosis factor (TNF) therapy.
\end{abstract}

Methods: Peripheral B cells from 18 RA patients and 13 healthy donors were characterized using flow cytometry. Eleven patients who underwent a six-month adalimumab therapy were further assessed for phenotypic changes on their B cells.

Results: RA patients exhibited a high percentage of naïve and memory B cells expressing CD86. In contrast, expression of FcyRllb was significantly reduced on RA memory B cells and plasmablasts as compared to healthy donors, probably due to downregulation of this receptor when differentiating from naive to memory cells. These alterations on FcyRllb were associated with high levels of anti-citrullinated vimentin autoantibodies. In addition, treatment with adalimumab normalized the expression of CD86 on memory B cells and reduced the expression of FcyRllb, mainly on naïve B cells.

Conclusions: Our findings show that peripheral B cells from RA patients have an altered expression of key molecules, such as CD86 and FcyRllb. Because this latter receptor is required for feedback inhibition, a deficient expression might contribute to humoral autoimmune responses. Furthermore, these molecules are likely to be influenced by inflammatory factors, since they were modulated by TNF inhibition.

\section{Introduction}

Rheumatoid arthritis (RA) is a chronic, inflammatory, and autoimmune disease that affects mainly synovial joints, leading to progressive destruction, pain, and disability. It is well known from mouse models that B cells play a pivotal role in the development of the autoimmune process as a precursor of antibody-secreting cells but also as antigen-presenting cells (APCs) [1,2].

\footnotetext{
* Correspondence: jaguillo@med.uchile.cl

'Programa Disciplinario de Inmunología, Instituto de Ciencias Biomédicas (ICBM), Facultad de Medicina, Universidad de Chile, Avenida Independencia 1027, Santiago, Chile
}

Immune cells express an array of receptors that bind the Fc portion of IgG-containing immune complexes (Fc $\gamma$ Rs). Particularly, it has been stated that B cells and plasma cells express only the low-affinity receptor Fc $\gamma$ RIIb, which, in contrast to FcrRIIa, has an immunoreceptor tyrosinebased inhibitory motif on the cytoplasmic domain. This characteristic confers an inhibitory function to the receptor which is essential in several checkpoint stages in which abnormal humoral responses are quenched by mechanisms that include the deletion of autoreactive clones and feedback inhibition of IgG secretion [3].

Given this property, it is not surprising that these molecules have been involved in autoimmune processes. 
Autoimmune-susceptible mice present several polymorphisms in the regulatory regions of the FcyRIIb gene, which result in a reduced expression of the receptor on germinal center B cells [4]. Moreover, depending on the strain, mice deficient in FcyRIIb can spontaneously develop a lupus-like syndrome, become susceptible to collagen-induced arthritis (CIA), or develop a severe phenotype of CIA or experimental autoimmune encephalomyelitis [5-8]. In contrast, overexpression of FcyRIIb on B cells, but not on macrophages, leads to an early resolution of CIA and reduced spontaneous lupus [9].

On the other hand, human autoimmune diseases characterized by a deregulated secretion of autoantibodies, such as systemic lupus erythematosus (SLE) and RA, have been associated with abnormalities in Fc $\gamma$ RIIb regulation. Polymorphisms in the promoter region as well as in the transmembrane domain of the Fc $\gamma$ RIIb gene have been described to affect the expression and function of this receptor, respectively [10-12]. While both polymorphisms in Fc $R$ RIIb are associated with SLE occurrence $[10,13]$, the one on the transmembrane domain is also associated with joint damage in RA [14]. Although alterations in the expression of Fc $\gamma$ RIIb on B cells have been described for other autoimmune diseases [15-18], no data about RA are available.

The aim of our study was to evaluate the phenotype of B cells from RA patients, focusing on their activation status and their expression of FcyRIIb. These parameters were compared with those obtained from B cells of healthy individuals. In addition, we followed up on these patients during anti-tumor necrosis factor (anti-TNF) therapy and assessed the phenotype of their B cells after 6 months of treatment. Our findings show that B cells from RA patients are activated, as reflected by the expression of CD86. We have also observed an altered expression of FcyRIIb, which is associated with the presence of autoantibodies. These abnormalities were shown to be partially reverted by anti-TNF therapy.

\section{Materials and methods Patients}

We recruited 18 patients meeting the American College of Rheumatology criteria for RA [19]. All of the patients were women, with a mean \pm standard deviation (SD) age of $52.8 \pm 10.5$ years and disease duration of $16.3 \pm 7$ years at study entry. All of them exhibited an active disease defined as at least six swollen joints, at least nine tender joints, and morning stiffness for more than 1 hour, regardless of being under treatment with diseasemodifying antirheumatic drugs. Disease activity was determined based on the disease activity score for 28 joints (DAS-28) [20]. Thirteen patients received $40 \mathrm{mg}$ of adalimumab (kindly provided by Abbott Laboratories,
Abbott Park, IL, USA) subcutaneously every other week during 24 weeks. The European League Against Rheumatism (EULAR) response criteria were used to establish the degree of response to treatment [21]. Thirteen healthy women were recruited as a control group, with a mean \pm SD age of $39.4 \pm 9.7$ years. For the analyses of CD86 expression, we had available samples of only 8 of the 13 healthy donors. Blood samples for flow cytometry analyses and serum determinations were drawn from RA patients at study entry and 6 months after beginning adalimumab administration. The study was approved by the Ethical Committee of the Hospital Clínico Universidad de Chile, and all patients and controls gave their written informed consent.

\section{Serum antibody determination}

Serum antibodies against modified and citrullinated vimentin (anti-MCV) were measured using a commercial enzyme-linked immunosorbent assay (ELISA) kit (Orgentec, Mainz, Germany) in accordance with the instructions of the manufacturer. The cutoff level was set at $20 \mathrm{U} / \mathrm{mL}$. Serum anti-cyclic citrullinated peptide (сcp) antibodies were detected using a commercial second-generation ELISA (Axis-Shield, Dundee, Scotland) in accordance with the instructions of the manufacturer. A cutoff level of $5 \mathrm{U} / \mathrm{mL}$ was considered. Total serum IgG levels were measured by ELISA at the Immunology Laboratory of the Hospital Clínico Universidad de Chile, and the range of concentrations considered normal was 639 to $1,349 \mathrm{mg} / \mathrm{dL}$.

\section{B-lymphocyte phenotyping}

We characterized $\mathrm{B}$ cells using the following monoclonal anti-human antibodies: anti-CD19 phycoerythrin (PE) cyanine 5 (Cy5), anti-CD27 fluorescein isothiocyanate (FITC), anti-CD27 PE, anti-CD86 FITC (BD Biosciences, San Jose, CA, USA), and anti-FcrRII PE (clone 7.3; Fitzgerald Industries International, Acton, MA, USA). For the staining procedure, anticoagulated whole blood was incubated with fluorescent antibodies for 30 minutes at $4^{\circ} \mathrm{C}$. Subsequently, red cells were lysed with ammonium chloride potassium (ACK) buffer, washed, and fixed for flow cytometry (FACSCalibur; BD Biosciences, San Jose, CA, USA). Data were analyzed with WinMDI 2.9 Software (TSRI Flow Cytometry Core Facility, La Jolla, CA, USA). A region was set to define the lymphocytic population according to forward and side scatter patterns. B cells were defined as CD19expressing cells, and a second region was set for them, while CD27 was used to discriminate memory from naïve subsets. Plasmablasts were defined as $\mathrm{CD} 19^{\text {low }}$ CD27 $7^{\text {high }}$-expressing cells (Figure 1a). Mean fluorescence intensity (MFI) was used as the analysis parameter for the expression of FcyRIIb. 
A

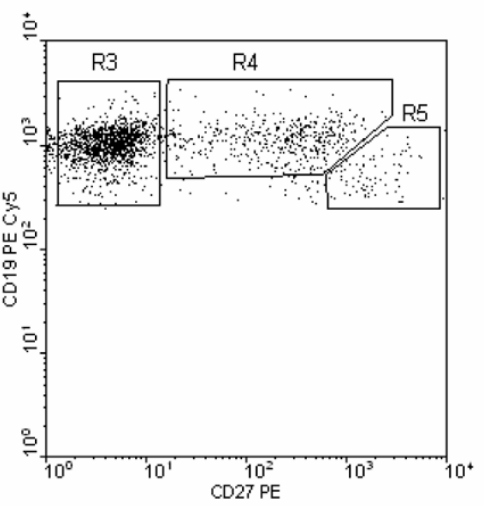

C

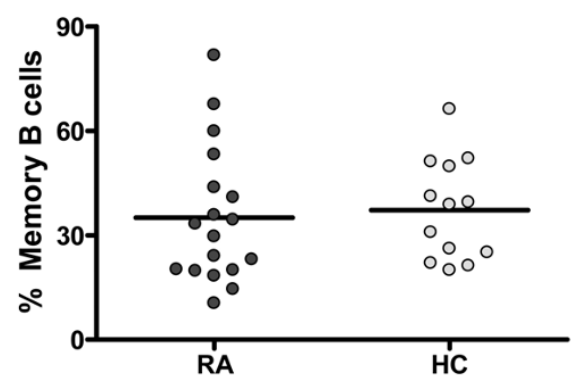

B

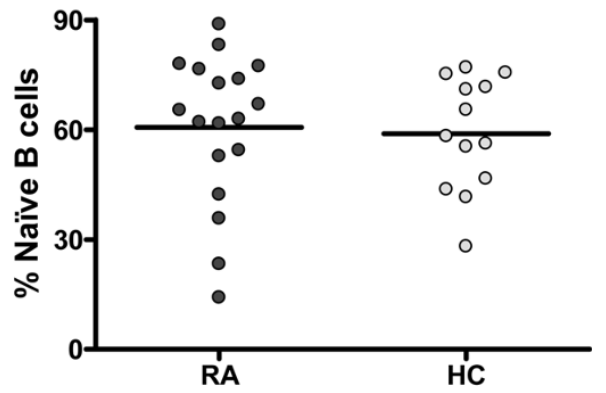

D

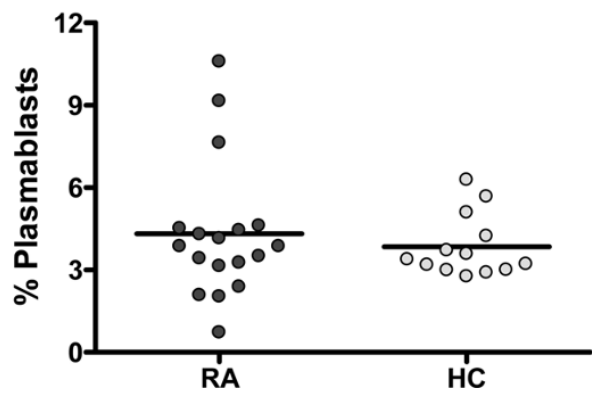

Figure 1 Characterization of B-cell subpopulations from rheumatoid arthritis (RA) patients and healthy controls (HCs). (a) Dot plot representing the distribution of naïve B cells (R3), memory B cells (R4), and plasmablasts (R5) which was used on further analyses. No differences in the percentages of naive B cells $\mathbf{( b )}$, memory B cells $\mathbf{( c )}$, and plasmablasts (d) between 18 RA patients and $13 \mathrm{HCs}$ were detected. $P>0.05$, two-tailed unpaired Student $t$ test. Horizontal lines represent mean values.

\section{Statistical analyses}

All of the study variables were tested for normality with the Shapiro-Wilk test. Differences between patient and control groups were analyzed using the two-tailed unpaired Student $t$ test or Mann-Whitney $U$ test, when appropriate. For comparisons between different B-cell subsets and for different adalimumab therapy time points, the two-tailed paired Student $t$ test or Wilcoxon signed-rank test were used, when appropriate. Correlations were evaluated with a two-tailed Spearman correlation test. For contingency analyses, a two-sided Fisher exact test was used. $P$ values of less than 0.05 were considered significant. For statistic analyses and graphics, GraphPad Prism 4 software (GraphPad Software, Inc., La Jolla, CA, USA) was used.

\section{Results}

Rheumatoid arthritis patients show peripheral B-cell frequencies similar to those of healthy controls Abnormalities in the frequency of B cells and in the proportion of different B-cell subsets in autoimmune diseases have been previously reported [22,23]. Despite a broad dispersion, we found no significant differences between RA and control subjects when comparing the percentage of $\mathrm{B}$ cells in the lymphocytic population (mean percentage \pm SD $7.5 \pm 3.1$ and $9 \pm 2.2$, respectively). Furthermore, when we discriminated B cells in naïve cells, memory cells and plasmablasts by means of CD19 and CD27 staining, we detected similar percentages of these subsets in the two groups of individuals (Figure 1).

Higher frequency of activated naïve and memory B cells in rheumatoid arthritis patients than in healthy controls

To assess the activation level of circulating B lymphocytes from RA patients, we analyzed CD86, a co-stimulatory molecule that increases its expression on B-cell surface upon activation $[24,25]$. We observed that RA patients have more CD86-expressing cells on the naïve and memory subsets than healthy controls do $(P=$ 0.042 and $P=0.017$, respectively), while no significant differences were observed for plasmablasts (Figure 2). 


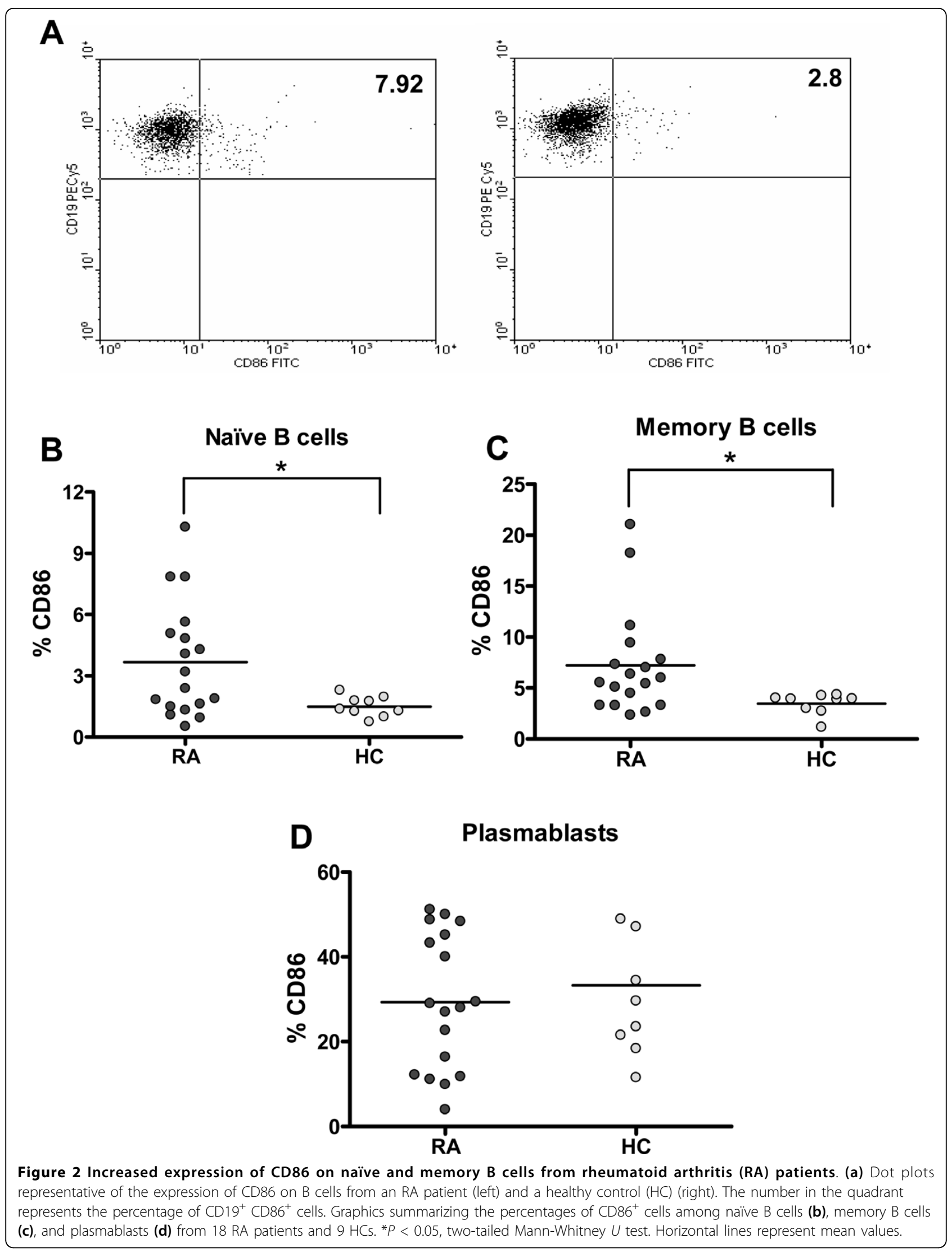


Reduced FcyRllb expression on memory B cells and plasmablasts from rheumatoid arthritis patients As for CD86, the evaluation of Fc $\gamma$ RIIb expression was carried out by analyzing each B-cell subset individually. We found that, although naïve B cells from RA patients and controls expressed similar levels of this receptor, its expression was significantly lower on RA memory B cells and plasmablasts $(P=0.0005$ and $P=0.0013$, respectively) (Figure 3$)$. No correlations were observed between FcyRIIb expression on B cells and disease activity or percentage of CD86-expressing B cells (data not shown).

There is evidence of a normal upregulation of Fc $\gamma$ RIIb following naïve B-cell activation and differentiation to a memory cell [15]. In our sample of healthy subjects, we detected that most individuals upregulate the expression of Fc $\gamma$ RIIb from naïve to memory B cells (8/13), in contrast with the RA group, in which 15 out of 18 patients were downregulators ( $\triangle$ MFI of greater than 10 between naïve and memory populations) $(P=0.029)$. This decrease of FcyRIIb expression on memory B cells as compared with naïve $B$ cells from RA patients was statistically significant $(P=0.0001)$ (Figure $4 b)$. We also noticed that RA patients show a further decrease in FcyRIIb expression on plasmablasts in comparison with memory B cells $(P=0.0001)$ (Figure $4 \mathrm{~b})$. A similar reduction was observed in healthy controls $(P=0.0002)$ (Figure 4c), although the expression levels reached by the healthy controls were still higher than those exhibited by RA patients (Figure 3c).

\section{FcyRIlb expression on B cells is associated with autoantibody levels}

As one of the main functions of Fc $\gamma$ RIIb on B cells is to control the development of autoimmunity by providing feedback inhibition in order to limit the secretion of autoantibodies, we assessed whether the levels of autoantibodies on RA patients were related to the expression of this inhibitory receptor on B cells. For this purpose, we measured serum anti-MCV antibodies since they have been described to be highly specific for RA [26]. Interestingly, RA patients negative for serum anti-MCV antibodies or with low levels (less than $50 \mathrm{U} / \mathrm{mL}$ ) displayed a higher expression of Fc $\gamma$ RIIb but only on memory B cells $(P=0.048)$ (Figure $5 \mathrm{a})$. Also, we found that all three patients who did not downregulate Fc $\gamma$ RIIb from naïve to memory $B$ cells exhibited no or very low titers of anti-MCV antibodies $(P=0.033)$ (Figure $5 b)$. We obtained similar results when we measured anti-ccp antibodies (data not shown). To evaluate whether this association was restricted to autoantibodies, we compared FcyRIIb expression on memory B cells in patients with normal (less than $1,350 \mathrm{mg} / \mathrm{dL}$ ) or high (at least $1,350 \mathrm{mg} / \mathrm{dL}$ ) levels of total serum IgG without

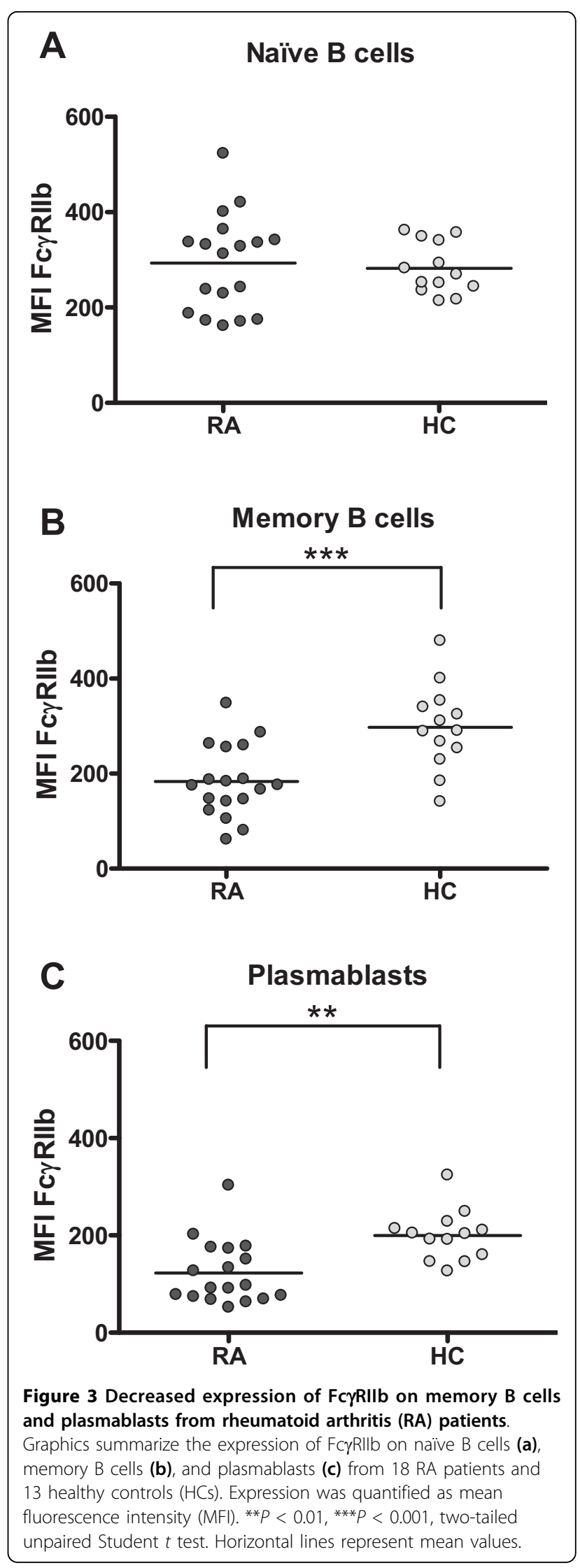




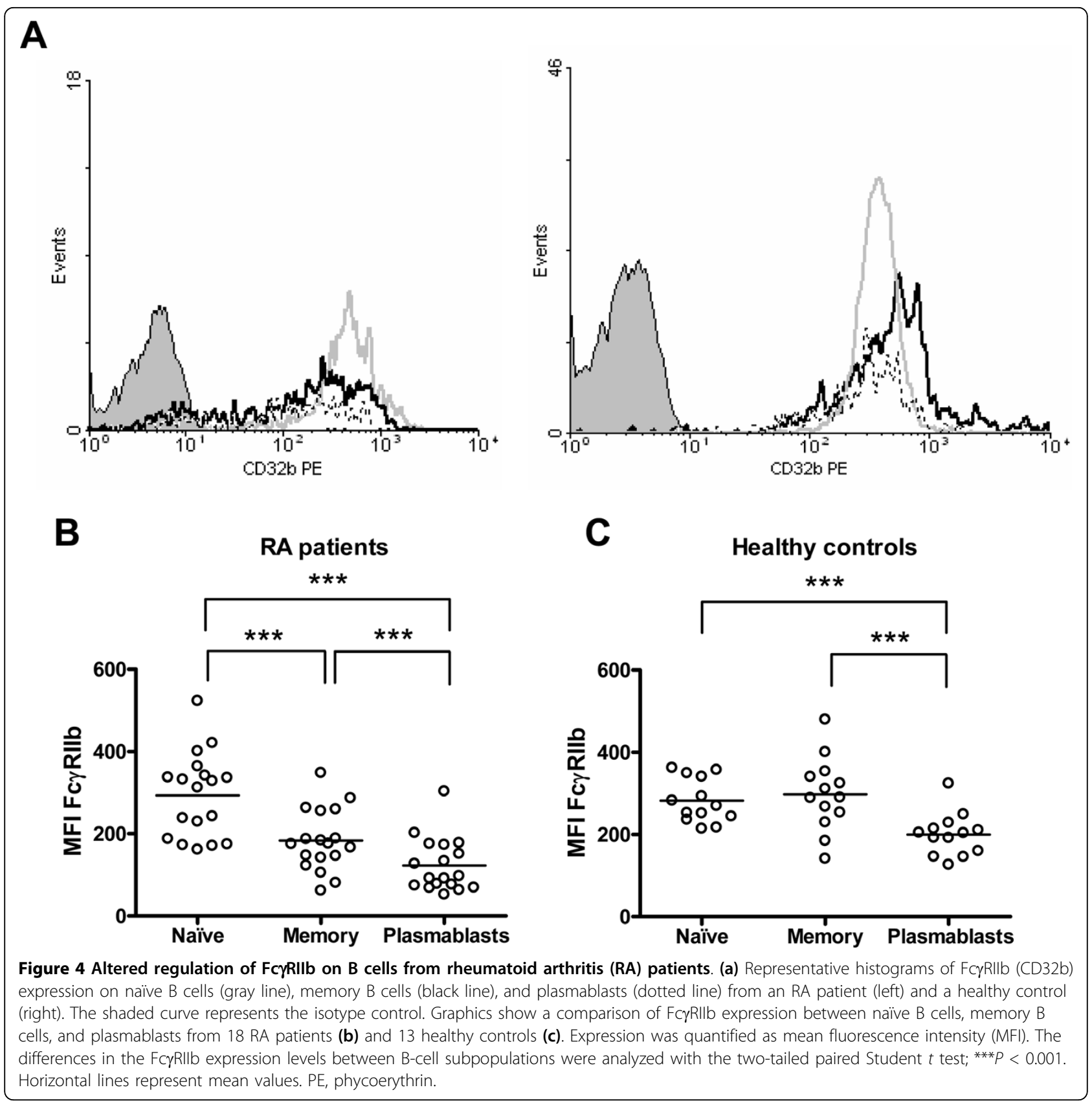

detecting significant differences between the two groups (Figure 5c).

Anti-tumor necrosis factor therapy can influence B-cell phenotype in rheumatoid arthritis patients

Next, we wanted to evaluate whether the alterations observed on RA patients' B cells could be reverted by the treatment with adalimumab. Of the 13 RA patients who completed 6 months of treatment with an antiTNF antibody (adalimumab), only 11 exhibited at least a moderate response according to the EULAR response criteria. In these patients, the percentage of total B cells as well as the proportion of naïve, memory, or plasmablast subsets remained unchanged (data not shown). However, the anti-TNF therapy caused a decrease in the proportion of memory B cells expressing CD86 after 6 months of therapy $(P=0.032)$ (Figure 6a). Notably, the change affecting CD86 paralleled a reduction in the intensity of Fc $\gamma$ RIIb expression, but this decrease reached significance on the naïve B-cell subpopulation only $(P=0.003)$ (Figure 6b). Consequently, there was an attenuation of the receptor downregulation observed 

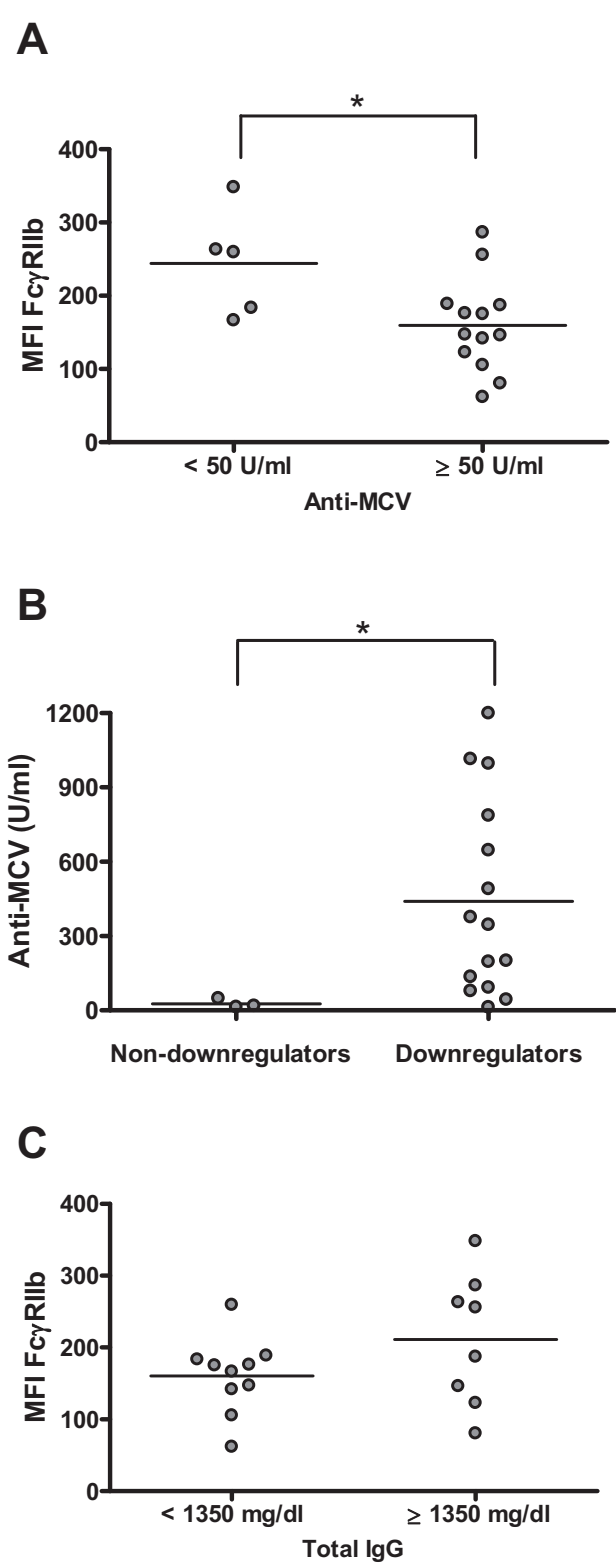

Figure 5 FcyRllb expression levels on rheumatoid arthritis (RA) patients' memory $B$ cells are inversely associated with antimodified and citrullinated vimentin (anti-MCV) titers. (a) FcyRllb expression on memory B cells from RA patients with high titers (at least $50 \mathrm{U} / \mathrm{mL}$ ) and from those with no or low titers (less than 50 $\mathrm{U} / \mathrm{mL}$ ) of serum anti-MCV antibodies. Expression was quantified as mean fluorescence intensity (MFI). ${ }^{*} P<0.05$, two-tailed MannWhitney $U$ test. (b) Anti-MCV antibody titers in patients who downregulated the expression of FcyRllb (the difference between MFI of naïve B cells and MFI of memory B cells was greater than 10 for downregulators) and in those who upregulated or maintained it almost invariable (the difference between MFI of naïve B cells and MFI of memory B cells was not greater than 10 for nondownregulators). ${ }^{*} P<0.05$, two-tailed Mann-Whitney $U$ test. (c) FcyRllb expression on memory B cells from RA patients with normal levels (less than 1,350 mg/dL) and high levels (at least 1,350 mg/dL) of total serum IgG. Expression was quantified as MFI. $P>0.05$, twotailed Mann-Whitney $U$ test. Horizontal lines represent mean values. before adalimumab treatment was started (Figure $4 \mathrm{~b}$ ), but the difference between naïve and memory B cells was still significant $(P=0.046)$ (Figure $6 \mathrm{c})$. In addition, anti-MCV antibody titers remained stable throughout this period (Figure $6 \mathrm{~d}$ ).

\section{Discussion}

In the present work, we provide evidence that phenotypic alterations on B cells from RA patients affect key molecules involved in the regulation of antigen presentation and antibody secretion functions. A major role of $B$ cells in the development and perpetuation of RA has been consistently demonstrated with the appearance of $\mathrm{B}$ cell-depleting therapy and its impressive results in reducing symptoms and preventing disease progression [27]. Studies on murine models have suggested that antigen-specific B cells are required as APCs for the induction of autoimmune arthritis, owing to their expression of MHC (major histocompatibility complex) class II and co-stimulatory molecules CD80 and CD86 $[28,29]$. CD86 is upregulated on activated B cells upon B-cell receptor (BCR) and CD19/CD21 complex engagement $[24,25]$. Our results show that RA patients have a higher proportion of naïve and memory $B$ cells expressing CD86 than healthy controls, reflecting an expanded activated status within these subpopulations, which is likely to favor a more productive interaction with pathogenic $\mathrm{T}$ cells. Analogous results have been reported for other inflammatory diseases, such as SLE [30-33], systemic sclerosis [34], asthma [35], and irritable bowel syndrome [36]. Presumably, constant stimulation of autoantigens through BCR and the influence of other proinflammatory signals, such as stimulation through Toll-like receptors (TLRs) [37], give rise to this activated phenotype. Also, it is probable that the effect of these activation stimuli could be attenuated by the cross-linking of IgG-containing immune complexes to their inhibitor receptor, Fc $\gamma$ RIIb, since studies on dendritic cells (DCs) have demonstrated that exposure to immune complexes together with a blockage of FcrRIIb is sufficient to induce an increase in the expression of CD86 $[38,39]$, whereas the overexpression of this receptor on murine $B$ cells reverses the induction of CD86 triggered via $B C R$ [9]. However, in a multifactorial complex disease such as RA, it is expected that the expression of this or other activation markers is influenced by a variety of factors as it is suggested by the absence of correlation between CD86-expressing B cells and Fc $\gamma$ RIIb expression levels found in our patients.

Our data show that RA patients present reduced levels of FcyRIIb on memory B cells and plasmablasts compared with healthy donors. This phenomenon can be explained by the abnormal downregulation of this receptor from naïve to memory B cells which we observed in 


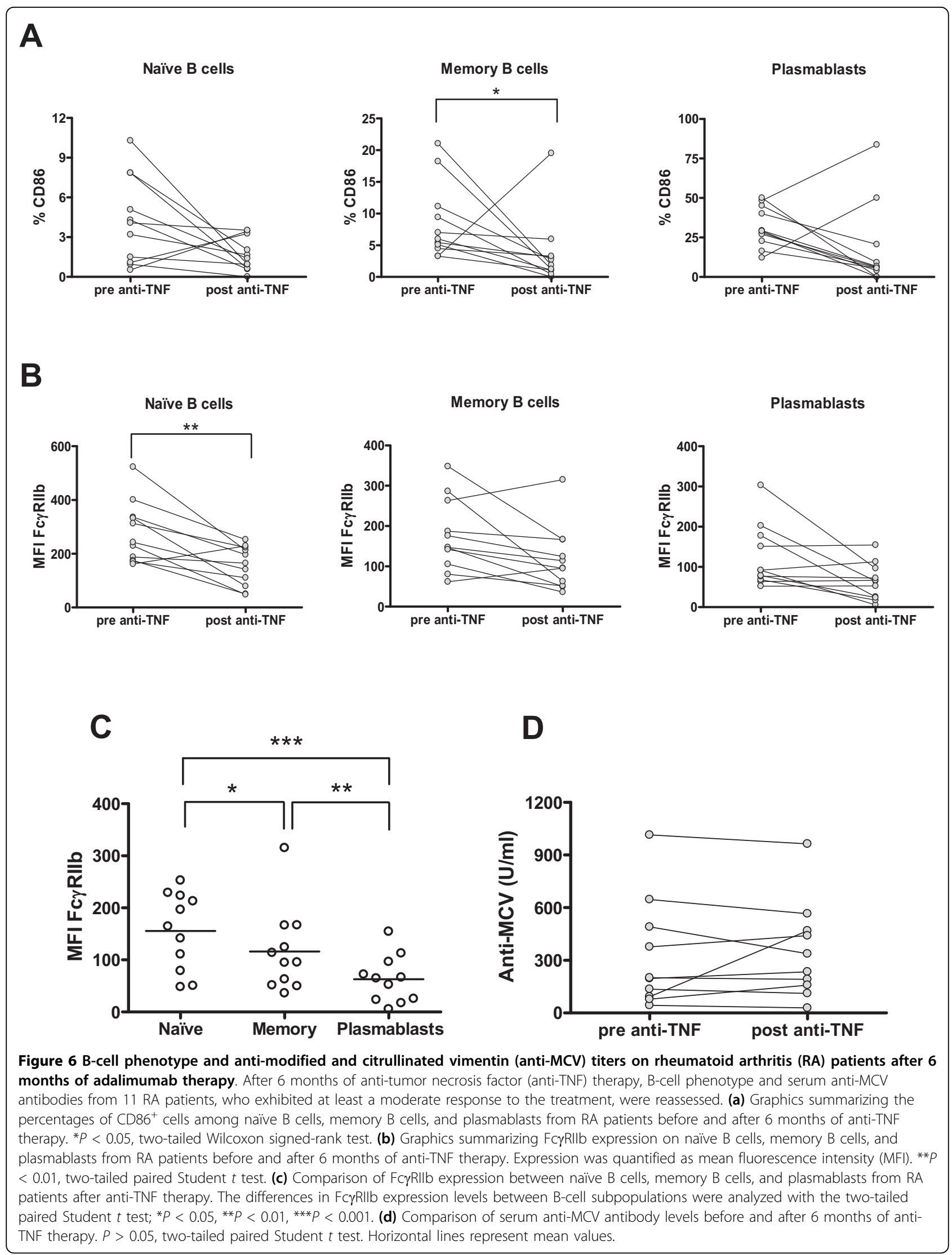


our RA group. These results are concordant with those seen in SLE and chronic inflammatory demyelinating polyneuropathy, other autoimmune diseases characterized by uncontrolled secretion of autoantibodies [15-18].

It has been postulated that Fc $\gamma$ RIIb upregulation might constitute a critical checkpoint in peripheral tolerance by providing an inhibitory feedback that limits the ongoing humoral response to self-antigens. In fact, in lupus-prone mice, the restoration of Fc $\gamma$ RIIb levels on B cells can revert the secretion of autoantibodies and renal disease [40]. Furthermore, the expression of this inhibitory receptor specifically on B cells, but not on macrophages, can be determinant for controlling autoimmunity in models of arthritis and lupus [9]. Through this work, we provide new evidence that may help to reinforce this concept as we have revealed, for the first time, an association between high levels of Fc $\gamma$ RIIb on memory B cells and no or low titers of specific autoantibodies, anti-MCV antibodies. This interesting result appears to be exclusive for autoimmune responses since we did not find a similar association when analyzing total IgG levels. It is noteworthy to consider that in this study we have examined only the expression of Fc $\gamma$ RIIb, but not its function, which if altered could also affect the regulatory ability over the humoral response against citrullinated proteins. Likewise, a recent publication has demonstrated an association between a functional polymorphism for Fc $\gamma R I I b$ and anti-ccp (+) RA in an Asian population [41].

After patients underwent 6 months of therapy with an anti-TNF antibody, we observed a decrease in CD86expressing memory $\mathrm{B}$ cells, reflecting an attenuation of the B-cell activated status. Paradoxically, Fc $\gamma$ RIIb expression on the naïve B-cell subset also decreased significantly. It has been demonstrated that Fc $\gamma$ RIIa and Fc $\gamma$ RIIb on human monocytes are differentially regulated by Th1/Th2 cytokines, with interferon-gamma favoring the activator receptor and interleukin-4 favoring the inhibitory receptor [42]. On the other hand, TNF downmodulates Fc $\gamma$ RIIb and FcyRIIa on monocytes, not affecting Fc $\gamma$ RIIa but reducing Fc $\gamma$ RIIb expression on DCs, while increasing Fc $\gamma$ RIIa without changing Fc $\gamma$ RIIb on neutrophils, indicating a tight cell-specific regulation [43-47]. To our knowledge, no studies addressing the effect of TNF over Fc $\gamma$ RIIb on human B cells have been published, but our results strongly suggest that TNF or other downstream cytokines may influence the expression of this receptor on B lymphocytes. In regard to RA, exposure of DCs to synovial fluid from RA patients has been shown to lead to an upregulation of Fc $\gamma$ RIIb [14] and an elevated expression of FcyRIIb has been demonstrated on RA synovial tissue, probably counteracting the upregulation of other activating receptors [48]. Some studies have reported that Fc $\gamma \mathrm{R}$ expression levels on leukocytes can vary with anti-rheumatic drugs, which would promote a more inhibitory profile [48-52]. It is possible that the reduction in Fc $\gamma$ RIIb expression that we observed on naïve $B$ cells as a consequence of anti-TNF therapy is accompanied by a decrease in the expression of activating receptors on these cells, like TLR9 and CD21, which would determine a restoration of the protective activator/inhibitor balance, but this issue needs to be investigated. The effect of TNF blockage, however, was not sufficient to prevent the downregulation of Fc $\gamma$ RIIb from naïve to memory B cells. These results are in accordance with the fact that our group of patients did not achieve a reduction in anti-MCV titers after 6 months of therapy. Others have reported that changes in these antibodies become significant after 18 months of anti-TNF therapy [53], so it is conceivable that a full normalization of B-cell phenotype may become apparent only over longer follow-up periods.

\section{Conclusions}

Our data demonstrate the existence of important alterations in the phenotype of peripheral B cells from RA patients, involving the expression of the co-stimulatory molecule CD86 and the inhibitory receptor FcyRIIb, the latter being associated with high titers of autoantibodies. We consider that our study contributes relevant evidence to a better comprehension of the molecular mechanisms that are implied in the regulation of B cells and the role that they play in the autoimmune response elicited in RA.

\section{Abbreviations}

APC: antigen-presenting cell; BCR: B-cell receptor; ccp: cyclic citrullinated peptide; CIA: collagen-induced arthritis; DC: dendritic cell; ELISA: enzymelinked immunosorbent assay; EULAR: European League Against Rheumatism; FcyR: Receptor for the Fc region of IgG-containing immune complexes; FITC: fluorescein isothiocyanate; MCV: modified and citrullinated vimentin; MFI: mean fluorescence intensity; PE: phycoerythrin; RA: rheumatoid arthritis; SD: standard deviation; SLE: systemic lupus erythematosus; TLR: Toll-like receptor; TNF: tumor necrosis factor.

\section{Acknowledgements}

We thank Nancy Fabres and Juana Orellana for their excellent technical assistance and Abbott Laboratories for providing the adalimumab doses. This work was supported by Fondecyt-Chile (grant 1090174) and Millenium Nucleus of Immunology and Immunotherapy (P07/088-F). DC is a recipient of a Conicyt Doctoral Fellowship.

\section{Author details}

${ }^{1}$ Programa Disciplinario de Inmunología, Instituto de Ciencias Biomédicas (ICBM), Facultad de Medicina, Universidad de Chile, Avenida Independencia 1027, Santiago, Chile. Sección de Reumatología, Departamento de Medicina, Hospital Clínico, Universidad de Chile, Santos Dumont 999, Santiago, Chile. ${ }^{3}$ Departamento de Genética Molecular y Microbiología, Facultad de Ciencias Biológicas, Pontificia Universidad Católica de Chile, Av. Bernardo O'Higgins 340, Santiago, Chile.

\section{Authors' contributions}

DC participated in the design of the study, carried out the acquisition and analysis of data, and drafted the manuscript. OA participated in B-cell 
phenotyping. FS coordinated the recruitment of patients, performed the clinical evaluations, and helped with data analysis. PW participated in the recruitment and clinical evaluations of patients. LS participated in the recruitment of patients and clinical data analysis. MC participated in the design and coordination of the study. AMK participated in the conception and design of the study and critically revised the manuscript. JCA participated in the conception and design of the study and in the interpretation of data and helped to draft the manuscript. All authors read and approved the final manuscript.

\section{Competing interests}

The authors declare that they have no competing interests.

Received: 23 January 2010 Revised: 25 March 2010

Accepted: 15 April 2010 Published: 15 April 2010

\section{References}

1. Korganow AS, Ji H, Mangialaio S, Duchatelle V, Pelanda R, Martin T, Degott C, Kikutani H, Rajewsky K, Pasquali JL, Benoist C, Mathis D: From systemic $T$ cell self-reactivity to organ-specific autoimmune disease via immunoglobulins. Immunity 1999, 10:451-461.

2. Takemura S, Klimiuk PA, Braun A, Goronzy JJ, Weyand CM: T cell activation in rheumatoid synovium is B cell dependent. J Immunol 2001, 167:4710-4718.

3. Nimmerjahn F, Ravetch JV: Fcgamma receptors as regulators of immune responses. Nat Rev Immunol 2008, 8:34-47.

4. Jiang Y, Hirose S, Abe M, Sanokawa-Akakura R, Ohtsuji M, Mi X, Li N, Xiu Y, Zhang D, Shirai J, Hamano Y, Fujii H, Shirai T: Polymorphisms in IgG Fc receptor IIB regulatory regions associated with autoimmune susceptibility. Immunogenetics 2000, 51:429-435.

5. Bolland S, Ravetch JV: Spontaneous autoimmune disease in Fc(gamma) RIIB-deficient mice results from strain-specific epistasis. Immunity 2000, 13:277-285.

6. Yuasa T, Kubo S, Yoshino T, Ujike A, Matsumura K, Ono M, Ravetch JV, Takai T: Deletion of fcgamma receptor IIB renders $\mathrm{H}-2(\mathrm{~b})$ mice susceptible to collagen-induced arthritis. J Exp Med 1999, 189:187-194.

7. Kleinau S, Martinsson P, Heyman B: Induction and suppression of collagen-induced arthritis is dependent on distinct fcgamma receptors. $J$ Exp Med 2000, 191:1611-1616.

8. Iruretagoyena MI, Riedel CA, Leiva ED, Gutierrez MA, Jacobelli SH, Kalergis AM: Activating and inhibitory Fcgamma receptors can differentially modulate T cell-mediated autoimmunity. Eur I Immunol 2008, 38:2241-2250.

9. Brownlie RJ, Lawlor KE, Niederer HA, Cutler AJ, Xiang Z, Clatworthy MR, Floto RA, Greaves DR, Lyons PA, Smith KG: Distinct cell-specific control of autoimmunity and infection by FcgammaRllb. J Exp Med 2008, 205:883-895

10. Blank MC, Stefanescu RN, Masuda E, Marti F, King PD, Redecha PB, Wurzburger RJ, Peterson MG, Tanaka S, Pricop L: Decreased transcription of the human FCGR2B gene mediated by the $-343 \mathrm{G} / \mathrm{C}$ promoter polymorphism and association with systemic lupus erythematosus. Hum Genet 2005, 117:220-227.

11. Floto RA, Clatworthy MR, Heilbronn KR, Rosner DR, MacAry PA, Rankin A, Lehner PJ, Ouwehand WH, Allen JM, Watkins NA, Smith KG: Loss of function of a lupus-associated FcgammaRllb polymorphism through exclusion from lipid rafts. Nat Med 2005, 11:1056-1058.

12. Kono H, Kyogoku C, Suzuki T, Tsuchiya N, Honda H, Yamamoto K, Tokunaga K, Honda Z: FcgammaRIIB lle232Thr transmembrane polymorphism associated with human systemic lupus erythematosus decreases affinity to lipid rafts and attenuates inhibitory effects on B cell receptor signaling. Hum Mol Genet 2005, 14:2881-2892.

13. Kyogoku C, Dijstelbloem HM, Tsuchiya N, Hatta Y, Kato H, Yamaguchi A, Fukazawa T, Jansen MD, Hashimoto H, Winkel van de JG, Kallenberg CG, Tokunaga K: Fcgamma receptor gene polymorphisms in Japanese patients with systemic lupus erythematosus: contribution of FCGR2B to genetic susceptibility. Arthritis Rheum 2002, 46:1242-1254.

14. Radstake TR, Franke B, Wenink MH, Nabbe KC, Coenen MJ, Welsing P, Bonvini E, Koenig S, Berg van den WB, Barrera P, van Riel PL: The functional variant of the inhibitory Fcgamma receptor Illb (CD32B) is associated with the rate of radiologic joint damage and dendritic cell function in rheumatoid arthritis. Arthritis Rheum 2006, 54:3828-3837.
15. Mackay M, Stanevsky A, Wang T, Aranow C, Li M, Koenig S, Ravetch JV, Diamond B: Selective dysregulation of the FcgammallB receptor on memory B cells in SLE. J Exp Med 2006, 203:2157-2164.

16. Su K, Yang H, Li X, Gibson AW, Cafardi JM, Zhou T, Edberg JC, Kimberly RP: Expression profile of FcgammaRllb on leukocytes and its dysregulation in systemic lupus erythematosus. J Immunol 2007, 178:3272-3280.

17. Isaak A, Gergely P Jr, Szekeres Z, Prechl J, Poor G, Erdei A, Gergely J: Physiological up-regulation of inhibitory receptors Fc gamma Rll and CR1 on memory B cells is lacking in SLE patients. Int Immunol 2008, 20:185-192.

18. Tackenberg B, Jelcic I, Baerenwaldt A, Oertel WH, Sommer N, Nimmerjahn F, Lunemann JD: Impaired inhibitory Fcgamma receptor IIB expression on B cells in chronic inflammatory demyelinating polyneuropathy. Proc Natl Acad Sci USA 2009, 106:4788-4792.

19. Arnett FC, Edworthy SM, Bloch DA, McShane DJ, Fries JF, Cooper NS, Healey LA, Kaplan SR, Liang MH, Luthra HS, Medsger TA, Mitchell DM, Neustadt DH, Pinals RS, Schaller JG, Sharp JT, Wilder RL, Hunder GG: The American Rheumatism Association 1987 revised criteria for the classification of rheumatoid arthritis. Arthritis Rheum 1988, 31:315-324.

20. Prevoo ML, van 't Hof MA, Kuper HH, van Leeuwen MA, Putte van de LB, van Riel PL: Modified disease activity scores that include twenty-eightjoint counts. Development and validation in a prospective longitudinal study of patients with rheumatoid arthritis. Arthritis Rheum 1995, 38:44-48.

21. van Gestel AM, Haagsma CJ, van Riel PL: Validation of rheumatoid arthritis improvement criteria that include simplified joint counts. Arthritis Rheum 1998, 41:1845-1850.

22. Odendahl M, Jacobi A, Hansen A, Feist E, Hiepe F, Burmester GR, Lipsky PE, Radbruch A, Dorner T: Disturbed peripheral B lymphocyte homeostasis in systemic lupus erythematosus. J Immunol 2000, 165:5970-5979.

23. Lindenau S, Scholze S, Odendahl M, Dorner T, Radbruch A, Burmester GR, Berek C: Aberrant activation of $B$ cells in patients with rheumatoid arthritis. Ann N Y Acad Sci 2003, 987:246-248.

24. Mongini PK, Tolani S, Fattah RJ, Inman JK: Antigen receptor triggered upregulation of CD86 and CD80 in human B cells: augmenting role of the CD21/CD19 co-stimulatory complex and IL-4. Cell Immunol 2002, 216:50-64.

25. Good KL, Avery DT, Tangye SG: Resting human memory B cells are intrinsically programmed for enhanced survival and responsiveness to diverse stimuli compared to naive B cells. J Immunol 2009, 182:890-901.

26. Dejaco C, Klotz W, Larcher H, Duftner C, Schirmer M, Herold M: Diagnostic value of antibodies against a modified citrullinated vimentin in rheumatoid arthritis. Arthritis Res Ther 2006, 8:R119.

27. Edwards JC, Szczepanski L, Szechinski J, Filipowicz-Sosnowska A, Emery P, Close DR, Stevens RM, Shaw T: Efficacy of B-cell-targeted therapy with rituximab in patients with rheumatoid arthritis. N Engl J Med 2004, 350:2572-2581.

28. O'Neill SK, Shlomchik MJ, Glant TT, Cao Y, Doodes PD, Finnegan A: Antigen-specific $B$ cells are required as APCs and autoantibodyproducing cells for induction of severe autoimmune arthritis. J Immunol 2005, 174:3781-3788.

29. O'Neill SK, Cao Y, Hamel KM, Doodes PD, Hutas G, Finnegan A: Expression of CD80/86 on B cells is essential for autoreactive $T$ cell activation and the development of arthritis. J Immunol 2007, 179:5109-5116.

30. Folzenlogen D, Hofer MF, Leung DY, Freed JH, Newell MK: Analysis of CD80 and CD86 expression on peripheral blood B lymphocytes reveals increased expression of CD86 in lupus patients. Clin Immunol Immunopathol 1997, 83:199-204.

31. Bijl M, Horst G, Limburg PC, Kallenberg CG: Expression of costimulatory molecules on peripheral blood lymphocytes of patients with systemic lupus erythematosus. Ann Rheum Dis 2001, 60:523-526.

32. Dolff S, Wilde B, Patschan S, Durig J, Specker C, Philipp T, Kribben A, Witzke $O$ : Peripheral circulating activated $b$-cell populations are associated with nephritis and disease activity in patients with systemic lupus erythematosus. Scand J Immunol 2007, 66:584-590.

33. Chang NH, McKenzie T, Bonventi G, Landolt-Marticorena C, Fortin PR, Gladman D, Urowitz M, Wither JE: Expanded population of activated antigen-engaged cells within the naive B cell compartment of patients with systemic lupus erythematosus. J Immunol 2008, 180:1276-1284.

34. Sato S, Fujimoto M, Hasegawa M, Takehara K: Altered blood B lymphocyte homeostasis in systemic sclerosis: expanded naive $B$ cells and diminished but activated memory B cells. Arthritis Rheum 2004, 50:1918-1927. 
35. Hofer MF, Jirapongsananuruk O, Trumble AE, Leung DY: Upregulation of B7.2, but not B7.1, on B cells from patients with allergic asthma. J Allergy Clin Immunol 1998, 101:96-102.

36. Ohman L, Lindmark AC, Isaksson S, Posserud I, Strid H, Sjövall H, Simrén M: B-cell activation in patients with irritable bowel syndrome (IBS). Neurogastroenterol Motil 2009, 21:644-650, e27.

37. Hanten JA, Vasilakos JP, Riter CL, Neys L, Lipson KE, Alkan SS, Birmachu W: Comparison of human $B$ cell activation by TLR7 and TLR9 agonists. BMC Immunol 2008, 9:39.

38. Dhodapkar KM, Kaufman JL, Ehlers M, Banerjee DK, Bonvini E, Koenig S, Steinman RM, Ravetch JV, Dhodapkar MV: Selective blockade of inhibitory Fcgamma receptor enables human dendritic cell maturation with IL12 p70 production and immunity to antibody-coated tumor cells. Proc Natl Acad Sci USA 2005, 102:2910-2915.

39. Kalergis AM, Ravetch JV: Inducing tumor immunity through the selective engagement of activating Fcgamma receptors on dendritic cells. J Exp Med 2002, 195:1653-1659.

40. McGaha TL, Sorrentino B, Ravetch JV: Restoration of tolerance in lupus by targeted inhibitory receptor expression. Science 2005, 307:590-593.

41. Chen JY, Wang CM, Ma CC, Hsu LA, Ho HH, Wu YJ, Kuo SN, Wu J: A transmembrane polymorphism in FcgammaRIlb (FCGR2B) is associated with the production of anti-cyclic citrullinated peptide autoantibodies in Taiwanese RA. Genes Immun 2008, 9:680-688.

42. Pricop L, Redecha P, Teillaud JL, Frey J, Fridman WH, Sautes-Fridman C, Salmon JE: Differential modulation of stimulatory and inhibitory FC gamma receptors on human monocytes by Th1 and Th2 cytokines. $J$ Immunol 2001, 166:531-537.

43. Liu Y, Masuda E, Blank MC, Kirou KA, Gao X, Park MS, Pricop L: Cytokinemediated regulation of activating and inhibitory Fc gamma receptors in human monocytes. J Leukoc Biol 2005, 77:767-776.

44. Wijngaarden S, Winkel van de JG, Jacobs KM, Bijlsma JW, Lafeber FP, van Roon JA: A shift in the balance of inhibitory and activating Fcgamma receptors on monocytes toward the inhibitory Fcgamma receptor Ilb is associated with prevention of monocyte activation in rheumatoid arthritis. Arthritis Rheum 2004, 50:3878-3887.

45. Liu Y, Gao X, Masuda E, Redecha PB, Blank MC, Pricop L: Regulated expression of FcgammaR in human dendritic cells controls crosspresentation of antigen-antibody complexes. J Immunol 2006 177:8440-8447.

46. Belostocki K, Park MS, Redecha PB, Masuda E, Salmon JE, Pricop L: FcgammaRlla is a target for modulation by TNFalpha in human neutrophils. Clin Immunol 2005, 117:78-86.

47. Guriec N, Daniel C, Le Ster K, Hardy E, Berthou C: Cytokine-regulated expression and inhibitory function of FcgammaRIIB1 and -B2 receptors in human dendritic cells. J Leukoc Biol 2006, 79:59-70.

48. Magnusson SE, Engstrom M, Jacob U, Ulfgren AK, Kleinau S: High synovial expression of the inhibitory FcgammaRllb in rheumatoid arthritis. Arthritis Res Ther 2007, 9:R51.

49. Wijngaarden S, van Roon JA, Winkel van de JG, Bijlsma JW, Lafeber FP: Down-regulation of activating Fcgamma receptors on monocytes of patients with rheumatoid arthritis upon methotrexate treatment. Rheumatology (Oxford) 2005, 44:729-734.

50. Wijngaarden S, Winkel van de JG, Bijlsma JW, Lafeber FP, van Roon JA: Treatment of rheumatoid arthritis patients with anti-TNF-alpha monoclonal antibody is accompanied by down-regulation of the activating Fcgamma receptor I on monocytes. Clin Exp Rheumatol 2008, 26:89-95.

51. Belostocki K, Pricop L, Redecha PB, Aydin A, Leff L, Harrison MJ, Salmon JE: Infliximab treatment shifts the balance between stimulatory and inhibitory Fcgamma receptor type II isoforms on neutrophils in patients with rheumatoid arthritis. Arthritis Rheum 2008, 58:384-388.

52. Torsteinsdottir I, Arvidson NG, Hallgren R, Hakansson L: Monocyte activation in rheumatoid arthritis (RA): increased integrin, Fc gamma and complement receptor expression and the effect of glucocorticoids. Clin Exp Immunol 1999, 115:554-560.

53. Nicaise Roland P, Grootenboer Mignot S, Bruns A, Hurtado M, Palazzo E, Hayem G, Dieude P, Meyer O, Chollet Martin S: Antibodies to mutated citrullinated vimentin for diagnosing rheumatoid arthritis in anti-CCPnegative patients and for monitoring infliximab therapy. Arthritis Res Ther 2008, 10:R142.

\section{doi:10.1186/ar2985}

Cite this article as: Catalán et al:: B cells from rheumatoid arthritis patients show important alterations in the expression of CD86 and Fc $\gamma$ RIlb, which are modulated by anti-tumor necrosis factor therapy. Arthritis Research \& Therapy 2010 12:R68.

\section{Submit your next manuscript to BioMed Central and take full advantage of:}

- Convenient online submission

- Thorough peer review

- No space constraints or color figure charges

- Immediate publication on acceptance

- Inclusion in PubMed, CAS, Scopus and Google Scholar

- Research which is freely available for redistribution

Submit your manuscript at www.biomedcentral.com/submit
C Biomed Central 